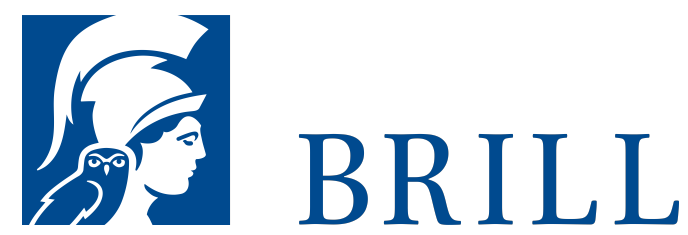

\title{
Descartes im Rückspiegel
}

Der Leib-Seele-Dualismus und das naturwissenschaftliche Weltbild

Author: Bernhard Lauth

Der cartesische Dualismus ist heute eine extrem unpopuläre Position. Das gilt sowohl für die Neurowissenschaften und die Psychologie als auch für den Grossteil der philosophischen Literatur zur Philosophie des Geistes. Lauth zeigt, dass es schon bei Descartes selbst - durchaus divergierende Lesarten des Leib-Seele-Dualismus gibt, die sich sehr deutlich durch ihre ontologischen Voraussetzungen und Konsequenzen unterscheiden. Im Mittelpunkt des Buches steht die Frage, unter welchen Voraussetzungen eine dualistische Ontologie in unser modernes naturwissenschaftliches Weltbild integriert werden kann.

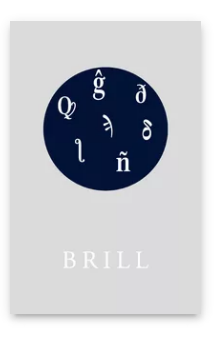

Pages: 242

Seiten

Language:

German

Subjects: Early

Modern

Philosophy,

Philosophy

Publisher: Brill | mentis

E-Book (PDF)

Released online:

o1 Jan 2006

ISBN: 978-3-

95743-840-9

Paperback

Publication date:

o1 Jan 2006

ISBN: 978-3-

89785-471-0 
For more information see brill.com

Order information: Order online at brill.com +44330 333 0049 | customerservices@brill.com Submission information: brill.com/authors

Titles published by Brill | Fink, Brill | mentis or Brill | Schöningh: +49(o)715413279216| brill@brocom.de 